\title{
Analysis of Metacognitive Ability and Critical Thinking Skills of Students in Integrated Islamic Education Institutions
}

\author{
Sukarno \\ UIN Sulthan Thaha Saifuddin Jambi \\ Email: sukarno@uinjambi.ac.id \\ AA. Musyafa \\ UIN Sulthan Thaha Saifuddin Jambi \\ Email: musyaffa@uinjambi.ac.id
}

\begin{abstract}
Metacognition and critical thinking skills are essential elements in creating good quality and competitive humans in the future. Therefore, this study aims to describe students' metacognitive abilities and critical thinking skills in Integrated Islamic Junior High School in Jambi. The writer uses a quantitative approach in this study and survey techniques to collect the data. There are 200 students from various Integrated Islamic Junior High Schools in Jambi involved in this study. After validating the data through validated instruments, the research reveals that: (1) The highest metacognitive ability of students at the Integrated Islamic Junior High School is in Procedural Knowledge (PK), which is an average value of 7.4 in the "good" category. Cognition Management $(P)$ and Management of Information Management (IMS), with an average score of 6.6 and 6.5, respectively, are in a suitable category. The lowest metacognitive ability is the ability of self-evaluation ability $(3,1)$ in the "low" category, while other abilities are in the "medium" category, (2) the critical thinking ability of students at Integrated Islamic Junior High School in Jambi is relatively good. As many as three of the five measured aspects are in the "good" category, and the rest (two aspects) are in the "medium" category. Thus, no aspect is measured to have the ability with the "low" category. In general, it shows that students' critical thinking on average at the Integrated Islamic Junior High School in Jambi have good critical thinking skills.
\end{abstract}

Keywords: Metacognition ability, critical thinking skills, integrated Islamic Junior High School

Abstrak: Kemampuan metakognisi dan keterampilan berpikir kritis merupakan dua elemen panting dalam menciptakan manusia yang bermutu dan berjiwa kompetitif dimasa depan. Oleh karena itu, penelitian ini bertujuan untuk mendeskripsikan kemampuan metakognisi dan keterampilan berpikir kritis siswa SMP Islam Terpadu di Jambi. Penelitian ini meggunakan pendekatan kuantitatif dengan teknik pengambilan data melalui teknik survey. Penelitian ini melibat 200 peserta didik dari berbagai sekolah SMP Islam Terpadu di Jambi. Berdasarkan data yang telah diambil dapat disimpulkan bahwa: (1) Kemampuan metakognisi tertinggi siswa pada sekolah SMP Islam Terpadu adalah pada Pengetahuan Prosedural (PK) yaitu nilai rata-rata 7,4 dengan kategori "baik". Selanjutnya disusul dengan kemampuan Pengaturan Kognisi (P) dan Manajemen pengelolaan informasi (IMS), yaitu masing-masing memiliki skor rata-rata 6,6 dan 6,5 dengan kategori baik. Adapun kemampuan metakognisi terendah adalah kemampuan Kemampuan 
evaluasi diri $(3,1)$ dengan kategori "rendah", sedangkan kemampuan lainnya berkategori "sedang", (2) kemampuan berpikir kritis siswa pada SMP Islam Terpadu di Jambi, relative sudah baik. Sebanyak tiga dari lima akpek yang diukur berada pada kategori "baik" dan sisanya (dua aspek) berada pada kategori "sedang". Dengan demikian tidak ada aspek yang diukur memiliki kemampuan dengan kategori "rendah". Hal itu menunjukkan bahwa secara umum atau rata-rata siswa di SMP Islam Terpadu di Jambi memiliki kemampuan berpikir kritis yang baik. Kemampuan tersebut dapat dilihat dari aspek: kemampuan dalam memberikan penjelasan sederhana,

Kata-kata kunci: Kemampuan metakognisi, keterampilan berpikir kritis, SMP Islam Terpadu

\section{Introduction}

As a perfect religion, Islam places a high value on the quality of human life. It means that Islamic teachings are relatively high status and the importance of science. Islam as a religion requires each of its adherents to pursue high knowledge. The term "knowledge" is listed 780 times in the Al-Qur'an'1. Misbahuddin mentions that the Al-Qur'an is a source of knowledge ${ }^{2}$. In fact, Allah always encourages scientists to observe the kingdoms of the heavens and the earth, as well as everything else that Allah has created, in order to be more convinced of God's power. Science, as an indicator of the quality of human life, holds an important place in Islam ${ }^{3}$.

The essence of Islam's knowledge comprises facilities, processes, and goals ${ }^{4}$. Science is the entire conscious effort to investigate, discover, and improve human understanding from various aspects of reality in the human realm ${ }^{5}$. The essence of knowledge in Islam is a means (facility) to increase faith and devotion to Allah ${ }^{6}$. Thus, the essence of this knowledge must receive serious attention from teachers during the Islamic education process. The focus is to ensure that learning in Islamic educational institutions is driven by and by the essence of knowledge.

In addition to understanding the nature of science, the success of an educational process is also caused by understanding the mastery of educational goals itself. The aim of Islamic education is to produce humans with good moral values, who can put things in the right place based on real honor, who will use the right methods to achieve the right goals, and who will struggle for anything to achieve the right goals ${ }^{7}$. Meanwhile, the aim of Islamic education is to produce students who are truthful, trustworthy, keep their promises, fair, enjoy helping others, and are consistent in their kindness ${ }^{8}$. The purpose of Islamic education is to develop a harmonious relationship with Allah, fellow humans, himself, and the

\footnotetext{
1'Faisal, F., Urgensitas Ilmu Menurut Konsep Islam. At-Tarbawi, 10(2), 2019: 51. Https://Doi.Org/10.32505/Tarbawi.V10i2.831', p. 831.

2 Misbahuddin, H. I., Keilmuan Dalam Al-Qur'an. Jurnal At-Taqaddum, 2014.

3 'Mulyono., Kedudukan Ilmu Serta Belajar Dalam Islam. Volume 4, 2009.', 4.

4'Kuswanjono, A., Hakikat Ilmu Dalam Pemikiran Islam. Jurnal Filsafat, 2016 Https://Doi.Org/10.22146/Jf.12787', p. 12787.

5 Mujib, A., Hakekat Ilmu Pengetahuan dalam Persfektif Islam. Ri'ayah: Jurnal Sosial Dan Keagamaan. 2019 https://doi.org/10.32332/riayah.v4i01.1504

${ }^{6}$ Misbahuddin, H. I, loc.cit.

${ }^{7}$ Sarjun., Konsep Ilmu Dalam Islam Dan Implikasinya Dalam Praktik Kependidikan. Al-Fikri., 2018, n.d.

8 Wicaksono, H., Tujuan Tujuan Pendidikan Islam Berbasis Mabādi 'Khaira Ummah. Edukasia Islamika, 2020 https://doi.org/10.28918/jei.v5i1.2426
} 
environment by practicing the aforementioned characteristics ${ }^{9}$. Meanwhile, the goal of Islamic education is to develop Muslim personalities ${ }^{10}$. As a result, it is clear that the ultimate purpose of Islamic education is to create humans who are selfaware enough to think and act in accordance with Islamic teachings.

Student learning outcomes are one indicator of whether educational objectives are met during the learning process. Learning outcomes are measured to determine the achievement of educational goals, so learning outcomes must be parallel with educational goals ${ }^{11}$. Educational goals must also be in line with each student's learning results ${ }^{12}$. As a result, the educational or learning process must be oriented toward achieving learning outcomes. Learning outcomes are abilities that students possess after undergoing a learning experience that results in behavioral changes ${ }^{13}$. Assessing learning outcomes should include cognitive, affective, and psychomotor domains ${ }^{14}$.

One of the most significant and determining factors, in line with the nature of science, the purpose of education in Islam, and student learning outcomes as mentioned above, is metacognition ability, which is a person's ability to be aware of his condition. Metacognition is a person's ability to understand and identify their own intelligence and thinking processes ${ }^{15}$. Metacognition is the ability to control one's own thoughts ${ }^{16}$. Metacognition is also known as a person's ability to recognize his own ability to learn, prepare, and act ${ }^{17}$. Lai (2011) wrote that metacognition consists of two components, namely knowledge, and regulation.

Metacognitive knowledge includes knowledge about oneself as a learner and the factors that can affect performance, knowledge about strategies, and knowledge about when and why to use strategies. Metacognitive regulation is the monitoring of a person's cognition and includes planning activities, awareness of

9 Asmarani, T., Abdussalam, A., \& Surahman, C., Konsep Muttaqīn dalam al-Qur'an dan Implikasinya Terhadap Tujuan Pendidikan Islam (Studi Analitis Terhadap Konsep al-Muttaqīn dalam Al-Qur'an). Murabby: Jurnal Pendidikan Islam, 2019 https://doi.org/10.15548/mrb.v2i1.328

10Sutiono, S., Filosofi Tujuan Pendidikan Islam. Al-Risalah, 2018 https://doi.org/10.34005/alrisalah.v8i2.370

11 Nfn Purwanto, “Tujuan Pendidikan Dan Hasil Belajar: Domain Dan Taksonomi," Jurnal Teknodik, April 4, 2019, 146, https://doi.org/10.32550/teknodik.v0i0.541.

12 Ulfa Kesuma, "Implementasi Tujuan Pendidikan Dalam Meningkatkan Hasil Belajar Siswa Di MTS Patra Mandiri Plaju Kota Palembang," Al-Tarbawi Al-Haditsah: Jurnal Pendidikan Islam 5, no. 2 (December 19, 2020),

https://doi.org/10.24235/tarbawi.v5i2.6387.

13 Prasetyo, A. A., \& Nabillah, T., Faktor Penyebab Rendahnya Hasil Belajar Siswa. Sesiomadika., 2019, n.d.

14 Maya Saftari and Nurul Fajriah, "Penilaian Ranah Afektif Dalam Bentuk Penilaian Skala Sikap Untuk Menilai Hasil Belajar,” Edutainment : Jurnal Ilmu Pendidikan Dan Kependidikan 7, no. 1 (August 17, 2019): 71-81, https://doi.org/10.35438/e.v7i1.164.

15 “Anindya, I. A. W., Mahrus, M., \& Hadiprayitno, G., Hubungan Kemampuan Metakognisi Siswa Dengan Hasil Belajar Ipa Melalui Penerapan Model Pembelajaran Berbasis Masalah di SMP Negeri 2 Kuripan. Jurnal Pendidikan Biologi. Https://Doi.Org/10.17977/Um052v10i2p66-73," 2019, n.d.

16 Matthew G. Rhodes, 'Metacognition', Teaching of Psychology, 46.2 (2019), 168-75 <https://doi.org/10.1177/0098628319834381>.

17 Nicholas Shea, 'Concept-metacognition', Mind \& Language, 35.5 (2020), 565-82 <https://doi.org/10.1111/mila.12235>. 
task understanding and performance, and evaluation of the effectiveness of monitoring processes and strategies ${ }^{18}$.

Metacognition has a very big role in human life both in the educational process and in daily life. Good metacognition skills have been shown to have an impact on learning outcomes in the educational process. This is consistent with the findings of research, which was discovered that metacognition abilities affect student learning outcomes ${ }^{19}$. In other studies, it is also stated that metacognition affects mathematics learning outcomes ${ }^{20}$, learning activities and problem-solving abilities $^{21}$ and the learning independence of students ${ }^{22}$. It is thus clear, that metacognition is an important element in achieving the goals of Islamic education. Therefore, the metacognition abilities of students must be developed in Islamic education units.

Efforts to increase and develop the metacognition abilities of students in Islamic educational institutions can be done in several ways. Certain learning models, according to several reports, can be used to improve this ability. Metacognition abilities can be improved relatively well through the use of the DDCT learning model ${ }^{23}$, learning problem-solving models of conflict-cognitive strategies ${ }^{24}$,digital classrooms ${ }^{25}$, discovery learning ${ }^{26}$, developing problem-based teaching materials ${ }^{27}$ and developing contextual-based learning tools ${ }^{28}$. Therefore,

18 T. M. Amabile et al., "Academic-Practitioner Collaboration In Management Research: A Case Of Cross-Profession Collaboration.," Academy of Management Journal 44, no. 2 (April 1, 2001): 418-31, https://doi.org/10.2307/3069464.

${ }^{19}$ Sukarno and M. El Widdah, 'The Effect of Students' Metacognition and Digital Literacy in Virtual Lectures during the Covid-19 Pandemic on Achievement in the "Methods and Strategies on Physics Learning” Course. Jurnal Pendidikan IPA Indonesia', 2020 <https://doi.org/10.15294/jpii.v9i4.25332>.

20 Ayu Arsya Ulichusna, Tri Hariyati Nur Indah Sari, and Ganjar Susilo, "Pengaruh Metakognisi Dan Keaktifan Belajar Siswa Terhadap Hasil Belajar Matematika," Kompetensi 12, no. 1 (June 29, 2019): 44-52, https://doi.org/10.36277/kompetensi.v12i1.21.

21 Azizah Amatur Rohman, Suci Yuniarti, and Besse Intan Permatasari, "Pengaruh Metakognisi Dan Kreativitas Terhadap Kemampuan Pemecahan Masalah Matematis Siswa Kelas X Ips Sma Negeri 4 Balikpapan Tahun Ajaran 2017/2018," De Fermat: Jurnal Pendidikan Matematika 1, no. 2 (December 9, 2018): 25-30,

https://doi.org/10.36277/defermat.v1i2.23.

22 St Nur Humairah, "Pengaruh Metakognisi, Konsep Diri Dan Kemandirian Belajar Terhadap Kemampuan Pemecahan Masalah Matematika Siswa Kelas Xi Ipa Sman 1 Gowa," Jurnal MSA (Matematika Dan Statistika Serta Aplikasinya) 8, no. 1 (July 6, 2020): 5, https://doi.org/10.24252/msa.v8i1.12454.

23 Nur'aini Nur'aini, 'Upaya Meningkatkan Kemampuan Metakognisi Melalui Strategi Pembelajaran PAI Berbasis DDCT Pada Mahasiswa Sekolah Tinggi Agama Islam Ibnu Sina Batam', Jurnal Pendidikan Agama Islam Al-Thariqah, 5.1 (2020), 10-18 <https://doi.org/10.25299/althariqah.2020.vol5(1).4682>.

24 Sukaisih, R., Muhali, M., \& Asy'ari, M., Meningkatkan Keterampilan Metakognisi Dan Berpikir Kritis Siswa Melalui Pembelajaran Model Pemecahan Masalah Dengan Strategi KonflikKognitif. Empiricism Journal., 2010, n.d.

${ }^{25}$ Abdul Latif Herlina Ahmad Ahmad Al Yakin, "Digital Classroom Untuk Meningkatkan Kemampuan Metakognisi Mahasiswa Dalam Pembelajaran Pkn,” Celebes Education Review 1, no. 2 (October 29, 2019): 71-79,

https://doi.org/10.37541/cer.v1i2.254.

26 Anisa, N. E., Rudibyani, R. B., \& Sofya, E., Pembelajaran Discovery Learning Untuk Meningkatkan Kemampuan Metakognisi Dan Penguasaan Konsep Siswa. Jurnal Pendidikan Matematika., 2017, n.d.

27 Nishfiya Ramdoniati, Muntari Muntari, and Saprizal Hadisaputra, "Pengembangan Bahan Ajar Kimia Berbasis Problem Based Learning Untuk Meningkatkan Keterampilan Metakognisi," 
teachers at Islamic education institutions, especially integrated Islamic schools, should be able to adapt these learning models, as well as developing teaching materials and learning tools to develop students' metacognitive abilities.

Apart from metacognition skills, critical thinking skills are also an important element in achieving the goals of Islamic education. Critical thinking is the most important skill in facing challenges and solving problems in everyday life ${ }^{29}$. One of the competencies that students must possess is the ability to think critically ${ }^{30}$. In the education and learning process, critical thinking skills are also very important. This ability has a positive effect on student mathematics learning outcomes ${ }^{31}$, physics learning outcomes ${ }^{32}$, history learning outcomes ${ }^{33}$. As a result, it is believed that the ability to think critically has a positive impact on students' potential success in the future.

According to researchers, there are many ways to help students improve their critical thinking skills. One of the attempts to develop students' critical thinking skills is to use teaching materials focused on interconnection integration ${ }^{34}$. Furthermore, the creation of immersive learning media based on metacognitive techniques will help enhance critical thinking skills. Several learning models can also be used as an effort to improve critical thinking skills, for example, the Experiential Learning Model $^{35}$, Discovery Learning model ${ }^{36}$, problem-based learning 37 , the Metacognitive Instruction approach ${ }^{38}$, the use of mind mapping

Jurnal Penelitian Pendidikan IPA 5, no. 1 (November $15, \quad$ 2018), https://doi.org/10.29303/jppipa.v5i1.148.

28 “Amir, M. F., \& Kusuma W, M. D., Pengembangan Perangkat Pembelajaran Berbasis Masalah Kontekstual Untuk Meningkatkan Kemampuan Metakognisi Siswa Sekolah Dasar. Journal of Medives: Journal of Mathematics Education IKIP Veteran Semarang., 2018, Https://Doi.Org/10.31331/Medives.V2i1.538," n.d.

29 Sulistiani, E., \& Masrukan., Pentingnya Berpikir Kritis Dalam Pembelajaran Matematika Untuk Menghadapi Tantangan MEA. Seminar Nasional Matematika X Universitas Semarang 2016., n.d.

30 Suparni Suparni, "Upaya Meningkatkan Kemampuan Berpikir Kritis Mahasiswa Menggunakan Bahan Ajar Berbasis Integrasi Interkoneksi,” Jurnal Derivat: Jurnal Matematika Dan Pendidikan Matematika 3, no. 2 (May 30, 2020): 40-58,

https://doi.org/10.31316/j.derivat.v3i2.716.

31 Maya Nurfitriyanti, Novrita Mulya Rosa, and Fatwa Patimah Nursa'adah, 'Pengaruh Kemampuan Berpikir Kritis, Adversity Quotient Dan Locus of Control Terhadap Prestasi Belajar Matematika', JKPM (Jurnal Kajian Pendidikan Matematika), $5.2 \quad$ (2020), 263 <https://doi.org/10.30998/jkpm.v5i2.5929>.

32 “Amto, A., Ertikanto, C., \& Nyeneng, I. D. P., Pengaruh Keterampilan Berpikir Kritis Melalui Pembelajaran Berbasis Aneka Sumber Belajar Terhadap Hasil Belajar Fisika Siswa. Jurnal Pendidikan Fisika., 2019, Https://Doi.Org/10.24127/Jpf.V7i1.1337," n.d.

33 Firdaus Hadi Santosa, Umasih Umasih, and Sarkadi Sarkadi, 'Pengaruh Model Pembelajaran Dan Kemampuan Berpikir Kritis Terhadap Hasil Belajar Sejarah Siswa Di SMA Negeri 1 Pandeglang', JTP - Jurnal Teknologi Pendidikan, 20.1 (2018), 13-27 <https://doi.org/10.21009/jtp.v20i1.6777>.

34 Suparni, loc.cit.

35 Dyahsih Alin Sholihah, Widha Nur Shanti, and Ahmad Anis Abdullah, 'Model Experiential Learning Untuk Meningkatkan Kemampuan Berpikir Kritis Mahasiswa Pendidikan Matematika', UNION: Jurnal Ilmiah Pendidikan Matematika, $7.3 \quad$ (2019), 383 <https://doi.org/10.30738/union.v7i3.5844>.

36 Amallia Nugrahaeni, I Wayan Redhana, and I Made Arya Kartawan, "Penerapan Model Pembelajaran Discovery Learning Untuk Meningkatkan Kemampuan Berpikir Kritis Dan Hasil Belajar Kimia," Jurnal Pendidikan Kimia Indonesia 1, no. 1 (December 12, 2017): 23, https://doi.org/10.23887/jpk.v1i1.12808.

37 Sudirman Rizki Ariyanto et al., "Problem Based Learning Dan Argumentation Sebagai Solusi Dalam Meningkatkan Kemampuan Berpikir Kritis Siswa SMK," Jurnal Kependidikan: Jurnal 
through project-based learning ${ }^{39}$, through the E-Learning Zoom application ${ }^{40}$. Thus it is clear that critical thinking skills are one of the basic elements and main indicators of achieving educational goals and learning outcomes in the perspective of Islamic education, namely the creation of humans who have the self-awareness to think and do according to Islamic teachings. Therefore, in the process of Islamic education, these variables should be the main focus.

Referring to the explanation above, the study aims to see, analyze, and describe the metacognitive abilities and critical thinking skills of students in integrated Islamic educational institutions, based on the above explanation that metacognition abilities and critical thinking skills are very important elements in achieving the goals of Islamic education. Thus, the focus of this research is to answer the question of students' metacognitive abilities and critical thinking skills in integrated Islamic education institutions?

To perform this study, the author uses the quantitative approach, which is a method of collecting, analyzing, and displaying data in numerical rather than narrative form ${ }^{41}$. While the techniques of data collection used in this study are surveys ${ }^{42}$. The data consist of metacognition abilities and critical thinking skills.

The metacognition awareness inventory (MAI) adaptation instrument was used to assess metacognition ability. MAI covers all aspects of metacognition and is divided into two parts: knowledge about cognition (which includes declarative knowledge (DK), procedural knowledge (PK), and conditional knowledge (CK), and control or cognitive management (which includes preparation (P), management information management (IMS), monitoring understanding (CM), and strategy correction (DS) and evaluation (E) ${ }^{43}$. The instrument used to asses critical thinking skills is in the form of essay questions adapted from the Illinois Critical Thinking Essay Test with science lessons as the context for the question ${ }^{44}$. The aspects of critical thinking skills measured in this study are: 1) the ability to provide simple explanations, 2) the ability to build basic skills, 3) the ability to provide additional

Hasil Penelitian Dan Kajian Kepustakaan Di Bidang Pendidikan, Pengajaran Dan Pembelajaran 6, no. 2 (July 4, 2020): 197,

https://doi.org/10.33394/jk.v6i2.2522.

38 Mega Achdisty Noordyana, "Meningkatkan Kemampuan Berpikir Kritis Matematis Siswa Melalui Pendekatan Metacognitive Instruction," Mosharafa: Jurnal Pendidikan Matematika 5, no. 2 (August 23, 2018): 120-27,

https://doi.org/10.31980/mosharafa.v5i2.267.

39 Fendy Hardian Permana and Dwi Setyawan, "Implementasi Mind Mapping Melalui Project Based Learning Untuk Meningkatkan Kemampuan Berpikir Kritis Dan Hasil Belajar," Jurnal Pijar Mipa 14, no. 1 (March 28, 2019): 50,

https://doi.org/10.29303/jpm.v14i1.1044.

40 "Septiyani, D. Y., Haji, S., \& Widada, W., Meningkatkan Kemampuan Berpikir Kritis Calon

Guru Matematika Melalui Aplikasi E-Learning Zoom Pada Mata Kuliah Microteaching Di Universitas Bengkulu. Jurnal Pendidikan Matematika Raflesia.," , 2020, n.d.

41 Sugeng, B., Fundamental Metodologi Penelitian Kuantitatif. In Komunikasi Penelitian Kuantitatif Program Studi Jurnalistik \& Humas., 2020, n.d.

42 David A. Story and Alan R. Tait, 'Survey Research', Anesthesiology, 130.2 (2019), 192-202 <https://doi.org/10.1097/ALN.0000000000002436>.

43 "Abdullah, R., \& Soemantri, D., Validasi Metacognitive Awareness Inventory Pada Pendidikan Dokter Tahap Akademik Validation of Metacognitive Awareness Inventory in Academic Stage of. (2018): 6(1). Https://Doi.Org/10.23886/Ejki.6.8621.Abstrak," n.d.

44 Zubaidah, S., Malang, U. N., \& Aloysius, D. C., Asesmen Berpikir Kritis Terintegrasi Tes Essay Asesmen Berpikir Kritis Terintegrasi Tes Essay. April 2015., 2018, n.d. 
explanations, 4) the ability to make estimates and integrations, and 5) the ability to draw conclusions ${ }^{45}$.

This study used a total sample of 200 students from different schools, regardless of gender or the number of students in each school. The participants are from An-Nahl Islamic Junior High School, Nurul 'Ilmi Integrated Islamic Junior High School, As-Sidiqi Boarding School Integrated Islamic Junior High School, and AlMutmainnah Integrated Islamic Junior High School. All of the schools are located in Jambi province. While data analysis was carried out using category and percentage classification on each indicator variable and described in a logical narrative.

\section{Students' metacognition abilities in integrated Islamic Junior High Schools}

The writer measures students' metacognition ability based on instruments. The instruments are provided by the metacognition awareness inventory (MAI) team as described above. Every aspect of metacognition that is measured has different indicators and maximum scores. Therefore, the average score obtained by students also varies. Based on the average score obtained, the ability category is determined as 200 students of the Integrated Islamic Junior High School in Jambi, as shown in Table 1 below.

Table 1. Junior high school students' metacognition abilities at an integrated Islamic school in Jambi

\begin{tabular}{|c|c|c|c|c|}
\hline $\begin{array}{l}\text { Metacognition } \\
\text { Aspects }\end{array}$ & Indicators & $\begin{array}{l}\text { Maxi- } \\
\text { mums } \\
\text { Score } \\
\end{array}$ & Mean & Category \\
\hline $\begin{array}{l}\text { Declarative } \\
\text { Knowledge } \\
\text { (DK) }\end{array}$ & $\begin{array}{l}\text { Knowing about, what is being } \\
\text { studied/done } \\
\text { Having knowledge about skills and } \\
\text { abilities as a student } \\
\text { Acquire knowledge through } \\
\text { presentations, demonstrations, } \\
\text { discussions }\end{array}$ & 4 & 3,7 & Good \\
\hline $\begin{array}{l}\text { Procedural } \\
\text { Knowledge } \\
(\mathrm{PK})\end{array}$ & $\begin{array}{l}\text { Students can apply knowledge to } \\
\text { complete a certain procedure. } \\
\text { Students know the process and when to } \\
\text { apply the process in various situations } \\
\text { Students can acquire knowledge } \\
\text { through discovery, cooperative } \\
\text { learning, and problem-solving }\end{array}$ & 8 & 7,4 & Good \\
\hline $\begin{array}{l}\text { Conditional } \\
\text { knowledge } \\
(\mathrm{CK})\end{array}$ & $\begin{array}{l}\text { Able to apply knowledge and skills } \\
\text { according to certain circumstances } \\
\text { Able to apply declarative and } \\
\text { procedural knowledge to certain } \\
\text { conditions } \\
\text { Know when and why to use learning } \\
\text { procedures }\end{array}$ & 5 & 3,4 & Moderate \\
\hline
\end{tabular}

45 'Rahmawati., I. (n.d.). Analisis Keterampilan Berpikir Kritis Siswa SMP.Pdf.' 


\begin{tabular}{|c|c|c|c|c|}
\hline $\begin{array}{l}\text { Cognition } \\
\text { Regulation }\end{array}$ & $\begin{array}{l}\text { Students can make learning plans } \\
\text { independently } \\
\text { Students can set learning goals } \\
\text { independently } \\
\text { Have mental readiness before studying }\end{array}$ & 7 & 6,6 & Good \\
\hline $\begin{array}{l}\text { Information } \\
\text { Management } \\
\text { System (IMS) }\end{array}$ & $\begin{array}{l}\text { Have the skills to process information } \\
\text { efficiently } \\
\text { Have a strategy for processing } \\
\text { information (for example, organize, } \\
\text { describe, summarize, selective focus) }\end{array}$ & 10 & 6,5 & Moderat \\
\hline $\begin{array}{l}\text { Monitoring } \\
\text { Understanding }\end{array}$ & $\begin{array}{l}\text { Able to assess the learning strategies } \\
\text { used }\end{array}$ & 7 & 5,2 & Moderate \\
\hline $\begin{array}{l}\text { Correction } \\
\text { strategy }\end{array}$ & $\begin{array}{l}\text { Able to correct misunderstanding and } \\
\text { self-performance }\end{array}$ & 5 & 3,3 & Moderate \\
\hline $\begin{array}{l}\text { Self- } \\
\text { evaluation } \\
\text { skills }\end{array}$ & $\begin{array}{l}\text { Able to evaluate the performance and } \\
\text { effectiveness of strategies after learning }\end{array}$ & 6 & 3,1 & Low \\
\hline Total & & 52 & 39,2 & Good \\
\hline
\end{tabular}

The information in table 1 above shows that the highest metacognition ability of students at the Integrated Islamic Junior High School is in Procedural Knowledge (PK), which is an average value of 7.4 in the "good" category. Then followed by the ability of Cognition Management (P) and Management of Information Management (IMS), which each had an average score of 6.6 and 6.5 in the "good" category. The lowest metacognition ability is the ability of selfevaluation ability $(3,1)$ in the "low" category, while other abilities are in the "medium" category. Thus, in general, the metacognition abilities of students at integrated Islamic junior high schools in Jambi province are in the "good" category.

The results of the ability measurement above (Table 1) show that the potential ability of students at the Integrated Islamic Junior High School in solving problems is relatively good. Concerning this, metacognition is one requirement for problem-

solving mastery ${ }^{46}$. The involvement of metacognition skills in problem-solving in the learning process has also been proven through several research results, for example, students with high category metacognition abilities have good problemsolving abilities at the planning, monitoring, and reflection stages ${ }^{47}$. In other study, it also found that metacognition abilities, namely awareness, regulation, and evaluation, were a determinant of student success in solving problems ${ }^{48}$. Thus it can be said that in general, students at integrated Islamic junior high schools can solve problems related to the educational process they are currently undergoing.

46 Prahesti Tirta Safitri et al., "Analisis Kemampuan Metakognisi Siswa Dalam Memecahkan Masalah Matematika Model PISA," Journal of Medives: Journal of Mathematics Education IKIP Veteran Semarang 4, no. 1 (January 16, 2020): 11,

https://doi.org/10.31331/medivesveteran.v4i1.941.

47 Rachmady, R., Anggo, M., \& Busnawir, B., "Analisis Metakognisi Dalam Pemecahan

Masalah Matematika Siswa SMP. Jurnal Pembelajaran Berpikir Matematika (Journal of Mathematics Thinking Learning).," 2019, n.d.

48 "Setyaningrum, D. U., Proses Metakognisi Siswa SMP Dalam Pemecahan Masalah Perbandingan Senilai Dan Berbalik Nilai. Mosharafa: Jurnal ....,"2020, n.d. 
Metacognition ability is the awareness that students have to gain knowledge independently and find solutions to the problems found ${ }^{49}$. In general, the "awareness" of students at Integrated Islamic Junior High Schools in independent learning as well. Of course, the awareness and ability of independent study have a positive impact on the success of students in taking the final examination of learning. Students who have high learning motivation and awareness of independent learning have a strong positive correlation to the success of medical student competency exams ${ }^{50}$. In light of this, in the current era of the COVID-19 pandemic (most students study independently at home), students at Integrated Islamic Junior High School, with good metacognition skills, are believed to have relatively good learning success as well.

Apart from being related to learning outcomes, in the form of mastery of concepts, metacognition abilities also positively impact students' scientific attitudes. This is a relationship between students 'metacognitive skills and students' scientific attitudes ${ }^{51}$. Metacognition emphasizes personal knowledge of students' thoughts or individual thought processes and procedures as thinkers and actors in order for individuals to be capable of tracking and regulating cognitive behaviour or mental processes ${ }^{52}$.

By referring to the research results above, the teacher needs to design various lessons that develop students' metacognitive abilities. Several learning models can be used for improving and developing students' metacognition abilities. Deep dialogue thinking (DDCT) learning model to improve students' metacognition abilities ${ }^{53}$.

Learning techniques using digital classrooms can also be used as an alternative to improve students' metacognition skills ${ }^{54}$. Guided inquiry was adequate and had a considerable measure of influence on improving students' metacognition skills. The use of specific particular teaching materials, for example, inquiry-based worksheets can also effectively improve students' metacognitive abilities $^{55}$ and the reflective-metacognitive learning model ${ }^{56}$. All of these are able to improve critical thinking skills, metacognitive skills, and metacognition

49 “Anita, A.-, \& Assagaf, S. L. H., Analisis Kemampuan Metakognisi Mahasiswa Calon Guru. Vox Edukasi: Jurnal Ilmiah Ilmu Pendidikan.

Https://Doi.Org/10.31932/ve.V10i1.259," 2019, n.d.

50 “Tridellya, F., Anisa, R., \& Damayanti, D. S., Korelasi Motivasi Dan Kesiapan Belajar Mandiri Terhadap Kelulusan Computer Based Test Uji Kompetensi Mahasiswa Program Profesi Dokter Universitas Islam Malang. Jurnal Bio Komplementer Medicine.,"2019, n.d.

51 Suriani Siregar, "Analisis Keterampilan Metakognitif Dan Sikap Ilmiah Siswa Melalui Metode Pembelajaran Inkuiri,” Biotik: Jurnal Ilmiah Biologi Teknologi Dan Kependidikan 7, no. 2 (November 30, 2019): 141,

https://doi.org/10.22373/biotik.v7i2.5665.

52 "Putri, K., \& Dirgantoro, S., M a t h 1 i n e Pendekatan Keterampilan Metakognitif Dalam Pembelajaran Matematika Metacognitive Skill Approach in Learning Mathematics. 3(1), 1-10.," 2018 3, no. 1 (n.d.): 1-10.

${ }^{53}$ Nur'aini, loc.cit. pp. 10-18

${ }^{54}$ Herlina Ahmad, Abdul Latif, Ahmad Al Yakin, 'Digital Classroom Untuk Meningkatkan Kemampuan Metakognisi Mahasiswa Dalam Pembelajaran Pkn', Celebes Education Review, 1(2), 71-79, 2019 <https://doi.org/10.37541/cer.v1i2.254>

55 'Widodo, F. S. L. W., Sofya, E., \& Efkar, T., Efektivitas Inkuiri Terbimbing Untuk Meningkatkan Keterampilan Metakognisi Siswa Materi Larutan Elektrolit Dan Non Elektrolit. Jurnal Pendidikan Dan Pembelajaran Kimia.', 2019.

56 Muhali, M., Sukaisih, R., \& Asy'ari, M., Implementasi Model Reflective-Metacognitive Learning Untuk Meningkatkan Kemampuan Berpikir Kritis, Keterampilan Metakognisi Dan Kesadaran Metakognisi. Empiricism Journal., 2020. 
awareness through. Thus the teacher has many alternatives in developing the metacognition abilities of students.

\section{Students' Critical Thinking Skills in integrated Islamic Junior High School}

Students' critical thinking skills are measured based on the instruments provided by the team from the Illinois Critical Thinking Essay Test as conducted by Zubaidah et al with the context is science subjects ${ }^{57}$. Every aspect of critical thinking skills is measured as an indicator measured by one essay question with a maximum score of 5 . Thus, if there are two indicators in the critical thinking aspect, the maximum score is 10. Therefore, the average score obtained by students is also different. Based on the average score obtained, the ability category is determined. The measurement involving 200 students at the Integrated Islamic Junior High School in Jambi was obtained as in Table 2 below.

Table 2. Students' Critical Thinking Ability at Integrated Islamic Junior High School in Jambi

\begin{tabular}{|c|c|c|c|c|}
\hline $\begin{array}{l}\text { Critical thinking } \\
\text { aspects }\end{array}$ & Indicators & $\begin{array}{l}\text { Maximum } \\
\text { score }\end{array}$ & Mean & Category \\
\hline $\begin{array}{l}\text { Ability to provide } \\
\text { simple } \\
\text { explanations }\end{array}$ & $\begin{array}{l}\text { Focusing questions } \\
\text { Asking questions that require } \\
\text { complex explanations }\end{array}$ & 10 & 8,2 & Good \\
\hline $\begin{array}{l}\text { ability to build } \\
\text { basic skills }\end{array}$ & $\begin{array}{l}\text { Make observations and elaborate } \\
\text { on the results of observations }\end{array}$ & 5 & 4,6 & Good \\
\hline $\begin{array}{l}\text { make a further } \\
\text { explanation }\end{array}$ & $\begin{array}{l}\text { Identify assumptions } \\
\text { Be able to define terms }\end{array}$ & 10 & 6,3 & Moderate \\
\hline $\begin{array}{l}\text { make forecasts } \\
\text { and integrations }\end{array}$ & Integrate with others & 5 & 4,4 & Good \\
\hline make conclusions & $\begin{array}{l}\text { Perform deductions and assess } \\
\text { the results of deductions } \\
\text { Performs an induction }\end{array}$ & 10 & 6,2 & Moderate \\
\hline Total & & 40 & 29,7 & Good \\
\hline
\end{tabular}

Table 2 shows that students' critical thinking skills at the Integrated Islamic Junior High School in Jambi are relatively good. As many as three of the five aspects measured are in the "good" category, and the rest (two aspects) are in the "medium" category. Thus, no aspect is measured to have the ability with the "low" category. It shows in general, or on average that students at the Integrated Islamic Junior High School in Jambi have good critical thinking skills. This ability can be seen from the following aspects: the ability to provide simple explanations, build essential skills, make further explanations, make estimates and integration, and make conclusions.

Referring to the opinion of Huda \& Rahman ${ }^{58}$, Annisa ${ }^{59}$, and Husnah ${ }^{60}$, they state that there is a significant relationship between critical thinking skills and

57 Zubaidah, S., Malang, U. N., \& Aloysius, D. C. (2018). Asesmen Berpikir Kritis Terintegrasi Tes Essay Asesmen Berpikir Kritis Terintegrasi Tes Essay. April 2015.

58 Huda, M. M., \& Rahman, L. (2020). Hubungan Keterampilan Berpikir Kritis Dengan Hasil Belajar Siswa Sekolah Dasar. Jurnal Pena Karakter. 
student learning outcomes. Thus, referring to the results of measuring these abilities (Table 2), it can be assumed that, in general, student learning outcomes in various subjects are relatively good. Besides, the ability to think critically is also closely related to the ability to solve problems. Critical thinking skills positively impact students' development of problem-solving abilities ${ }^{61}$. The ability to think critically also affects a person's ability to make decisions ${ }^{62}$. Because people who can think critically tend to have good learning outcomes, good problem-solving abilities, and have good decision-making abilities as well.

Regarding religious tolerance, the ability to think critically also has a positive impact on this attitude. Critical thinking skills are related to high religious tolerance and vice versa, and low critical thinking skills are related to low religious tolerance ${ }^{63}$. More generally, the ability to think critically can build students' sensitivity in protecting and preserving the environment sustainably ${ }^{64}$. Thus, it can be understood that the ability to think critically and have a positive impact on the development of cognition and knowledge of students while studying at school is also able to increase positive attitudes towards environmental sustainability and attitudes of religious tolerance.

Seeing the urgency of critical thinking skills as described above, teachers need to continue to maintain and develop students' critical thinking skills. According to several studies, there are several strategies to improve students' critical thinking skills. The efforts to improve students' critical thinking skills in the learning process are developing or applying specific models. Several learning models that have been proven to improve critical thinking skills include discovery learning which increases critical thinking skills by up to $85 \% 65$. In addition, Problem Based Learning can also improve students' critical thinking skills with an achievement of $82.68 \% 66$. Besides, a research learning conveyed that critical

59 Lathifah Annisa, Chestalita Oktaviana, and Abdul Aziz Habibi, 'Hubungan Keterampilan Berpikir Kritis Dengan Hasil Belajar Peserta Didik', Edubiologica Jurnal Penelitian Ilmu Dan Pendidikan Biologi, 8.1 (2020), 35 <https://doi.org/10.25134/edubiologica.v8i1.2337>.

60 'Husnah, M. (2017). Hubungan Tingkat Berpikir Kritis Terhadap Hasil Belajar Fisika Siswa Dengan Menerapkan Model Pembelajaran Problem Based Learning. Journa of Physics and Science Learning (PASCAL).'

61 Sukaisih, R., Muhali, M., \& Asy'ari, M. (2020). Meningkatkan Keterampilan Metakognisi Dan Berpikir Kritis Siswa Melalui Pembelajaran Model Pemecahan Masalah Dengan Strategi Konflik-Kognitif. Empiricism Journal., 2020.

62 Dini Sharfina, Hubungan Berpikir Kritis Perawat Dalam Proses Pengambilan Keputusan

Keperawatan (Open Science Framework, September, $28^{\text {th }}$ 2019) <https://doi.org/10.31219/osf.io/zjh82>.

63 Jurusan Psikologi Universitas Pendidikan Indonesia and others, 'Keterampilan Berpikir Kritis Dan Perannya Terhadap Toleransi Beragama Murid SMA', Mediapsi, 6.2 (2020), 119-31 <https://doi.org/10.21776/ub.mps.2020.006.02.6>.

64 'Puspitasari, E., Sumarmi, \& Ach Amirudin., Integrasi Berpikir Kritis Dan Peduli Lingkungan Melalui Pembelajaran Geografi Dalam Membentuk Karakter Peserta Didik SMA. Jurnal Pendidikan: Teori, Penelitian, Dan Pengembangan, (2016):1(2), 122-126.'.

65 Dianita Eka Prasasti, Henny Dewi Koeswanti, and Sri Giarti, 'Peningkatan Keterampilan Berpikir Kritis Dan Hasil Belajar Matematika Melalui Model Discovery Learning Di Kelas IV SD', Jurnal Basicedu, 3.1 (2019), 174-79 <https://doi.org/10.31004/basicedu.v3i1.98>.

66 Wahyu Purnaningsih, Stefanus Christian Relmasira, and Agustina Tyas Asri Hardini, 'Upaya Peningkatan Kemampuan Berpikir Kritis Dan Hasil Belajar Tematik Melalui Model Problem Based Learning (PBL) Kelas V SD', Naturalistic: Jurnal Kajian Penelitian Pendidikan Dan Pembelajaran, 3.2 (2019), 367-75 <https://doi.org/10.35568/naturalistic.v3i2.406>. 
thinking and student learning outcomes improve using the Group Investigation learning model 67.

It is essential to increase and develop students' critical thinking skills. Critical thinking is the most crucial skill in facing challenges and solving problems in everyday life ${ }^{68}$. The ability to think critically is one of the skills of the 21st century, in addition to problem-solving, creativity and innovation, communication, and collaboration skills ${ }^{69}$. For this reason, the ability to think critically is one of the important elements in preparing human resources in the future. In other words, students from the Integrated Islamic Junior High School in Jambi have a pretty good chance to actively participate in building the civilization of the Indonesian nation in the future.

\section{Closing}

As previously explained, the research aims to describe the metacognition abilities and critical thinking skills of students of the Integrated Islamic Junior High School in Jambi. Whereas based on the data that has been taken through validated instruments, at the end of the research it can be concluded that:

Table 1 shows that students at the Integrated Islamic Junior High School have the highest metacognition ability in the Procedural Knowledge (PK) group, with an average score of 7.4. The skill of Cognition Management (P) and Management of Information Management (IMS) was next, with a 6.6 and 6.5 average score in the good category, respectively. The skill of self-evaluation ability $(3,1)$ is the lowest metacognition ability in the "low" category, whereas other abilities are in the "medium" category. As a result, the metacognition abilities of students at integrated Islamic junior high schools in Jambi province can be described as "good."

Table 2 shows that students' critical thinking skills at the Integrated Islamic Junior High School in Jambi are relatively good. Three of the five assessed aspects fall into the "good" category, while the remaining two falls into the "medium" category. As a result, no aspect is categorized as "low" in terms of ability. It demonstrates that students at the Integrated Islamic Junior High School in Jambi, on average, have strong critical thinking skills. The ability to provide simple explanations, develop basic skills, make more explanations, make assumptions and integrations, and draw conclusions are all examples of this ability.

67 Agnes Kumbaraningtyas, Stefanus Christian Relmasira, and Agustina Tyas Asri Hardini, "Penerapan Model Cooperative Learning Tipe Group Investigation Untuk Meningkatkan Berpikir Kritis Dan Hasil Belajar Siswa," Jurnal Pendidikan Glasser 3, no. 1 (April 3, 2019): 48, <https://doi.org/10.32529/glasser.v3i1.215>.

68 Sulistiani, E., \& Masrukan., Pentingnya Berpikir Kritis Dalam Pembelajaran Matematika Untuk Menghadapi Tantangan MEA. Seminar Nasional Matematika X Universitas Semarang 2016., 201.

69 "Redhana, I. W., Mengembangkan Keterampilan Abad Ke-21 Dalam Belajar Kimia. Jurnal Inovasi Pendidikan Kimia, 13(1), 2239 - 2253.," 2019 13, no. 1 (n.d.): 2239-53. 


\section{Bibliography}

'Abdullah, R., \& Soemantri, D., Validasi Metacognitive Awareness Inventory

Pada Pendidikan Dokter Tahap Akademik Validation of Metacognitive Awareness Inventory in Academic Stage of 2018: 6(1).

Https://Doi.Org/10.23886/Ejki.6.8621.Abstrak'

Amabile, T. M., C. Patterson, J. Mueller, T. Wojcik, S. J. Kramer, P. W. Odomirok, and others, 'Academic-Practitioner Collaboration In Management Research: A Case Of CrossProfession Collaboration.', Academy of Management Journal, 44.2 (2001), 418-31 <https://doi.org/10.2307/3069464>

'Amir, M. F., \& Kusuma W, M. D., Pengembangan Perangkat Pembelajaran Berbasis Masalah Kontekstual Untuk Meningkatkan Kemampuan Metakognisi Siswa Sekolah Dasar. Journal of Medives: Journal of Mathematics Education IKIP Veteran Semarang, 2018 Https://Doi.Org/10.31331/Medives.V2i1.538'

'Amto, A., Ertikanto, C., \& Nyeneng, I. D. P., Pengaruh Keterampilan Berpikir Kritis Melalui Pembelajaran Berbasis Aneka Sumber Belajar Terhadap Hasil Belajar Fisika Siswa. Jurnal Pendidikan Fisika, 2019 Https://Doi.Org/10.24127/Jpf.V7i1.1337'

'Anindya, I. A. W., Mahrus, M., \& Hadiprayitno, G. (2019). Hubungan Kemampuan Metakognisi Siswa Dengan Hasil Belajar Ipa Melalui Penerapan Model Pembelajaran Berbasis Masalah Di SMP Negeri 2 Kuripan. Jurnal Pendidikan Biologi. Https://Doi.Org/10.17977/Um052v10i2p66-73'

Anisa, N. E., Rudibyani, R. B., \& Sofya, E., Pembelajaran Discovery Learning Untuk Meningkatkan Kemampuan Metakognisi Dan Penguasaan Konsep Siswa. Jurnal Pendidikan Matematika, 2017.

'Anita, A.-, \& Assagaf, S. L. H., Analisis Kemampuan Metakognisi Mahasiswa Calon Guru, VOX Edukasi: Jurnal Ilmiah Ilmu Pendidikan. 2019 Https://Doi.Org/10.31932/ve.V10i1.259'

Annisa, Lathifah, Chestalita Oktaviana, and Abdul Aziz Habibi, 'Hubungan Keterampilan Berpikir Kritis Dengan Hasil Belajar Peserta Didik', Edubiologica Jurnal Penelitian Ilmu Dan Pendidikan Biologi, 8.1 (2020), 35 $<$ https://doi.org/10.25134/edubiologica.v8i1.2337>

Ariyanto, Sudirman Rizki, Ikke Wulan Puji Lestari, Savira Uswatun Hasanah, Latifahtur Rahmah, and Devi Vitriana Purwanto, 'Problem Based Learning Dan Argumentation Sebagai Solusi Dalam Meningkatkan Kemampuan Berpikir Kritis Siswa SMK', Jurnal Kependidikan: Jurnal Hasil Penelitian Dan Kajian Kepustakaan Di Bidang Pendidikan, Pengajaran Dan Pembelajaran, 6.2 (2020), 197 <https://doi.org/10.33394/jk.v6i2.2522>

'Faisal, F., Urgensitas Ilmu Menurut Konsep Islam. At- Tarbawi, 10(2), 2019: 51. Https://Doi.Org/10.32505/Tarbawi.V10i2.831'

Hadi Santosa, Firdaus, Umasih Umasih, and Sarkadi Sarkadi, 'Pengaruh Model Pembelajaran Dan Kemampuan Berpikir Kritis Terhadap Hasil Belajar Sejarah Siswa Di SMA Negeri 1 Pandeglang', JTP - Jurnal Teknologi Pendidikan, 20.1 (2018), 13-27 <https://doi.org/10.21009/jtp.v20i1.6777>

Herlina Ahmad, Abdul Latif, Ahmad Al Yakin, 'Digital Classroom Untuk Meningkatkan Kemampuan Metakognisi Mahasiswa Dalam Pembelajaran Pkn', Celebes Education Review, 1.2 (2019), 71-79 <https://doi.org/10.37541/cer.v1i2.254>

Huda, M. M., \& Rahman, L., Hubungan Keterampilan Berpikir Kritis Dengan Hasil Belajar Siswa Sekolah Dasar. Jurnal Pena Karakter. 2020

Humairah, St Nur, 'Pengaruh Metakognisi, Konsep Diri Dan Kemandirian Belajar Terhadap Kemampuan Pemecahan Masalah Matematika Siswa Kelas XI IPA SMAN 1 Gowa', Jurnal MSA (Matematika Dan Statistika Serta Aplikasinya), 8.1 (2020), 5 <https://doi.org/10.24252/msa.v8i1.12454> 
'Husnah, M. (2017). Hubungan Tingkat Berpikir Kritis Terhadap Hasil Belajar Fisika Siswa Dengan Menerapkan Model Pembelajaran Problem Based Learning. Journa of Physics and Science Learning (Pascal).'

Jurusan Psikologi Universitas Pendidikan Indonesia, Indra Nugraha, Sri Maslihah, Jurusan Psikologi Universitas Pendidikan Indonesia, Ifa Hanifah Misbach, and Jurusan Psikologi Universitas Pendidikan Indonesia, 'Keterampilan Berpikir Kritis Dan Perannya Terhadap Toleransi Beragama Murid SMA', Mediapsi, 6.2 (2020), 11931 <https://doi.org/10.21776/ub.mps.2020.006.02.6>

Kesuma, Ulfa, 'Implementasi Tujuan Pendidikan Dalam Meningkatkan Hasil Belajar Siswa Di Mts Patra Mandiri Plaju Kota Palembang', Al-Tarbawi Al-Haditsah: Jurnal Pendidikan Islam, 5.2 (2020)

<https://doi.org/10.24235/tarbawi.v5i2.6387>

Kumbaraningtyas, Agnes, Stefanus Christian Relmasira, and Agustina Tyas Asri Hardini, 'Penerapan Model Cooperative Learning Tipe Group Investigation Untuk Meningkatkan Berpikir Kritis Dan Hasil Belajar Siswa', Jurnal Pendidikan Glasser, 3.1 (2019), 48

<https://doi.org/10.32529/glasser.v3i1.215>

'Kuswanjono, A., Hakikat Ilmu Dalam Pemikiran Islam. Jurnal Filsafat, 2016 Https://Doi.Org/10.22146/Jf.12787'

Misbahuddin, H. I., Keilmuan Dalam Al-Qur'an. Jurnal At-Taqaddum, 2014.

Muhali, M., Sukaisih, R., \& Asy'ari, M. (2020). Implementasi Model Reflective-Metacognitive Learning Untuk Meningkatkan Kemampuan Berpikir Kritis, Keterampilan Metakognisi Dan Kesadaran Metakognisi. Empiricism Journal.

'Mulyono., Kedudukan Ilmu Serta Belajar Dalam Islam. Volume 4, 2009.', 4

Noordyana, Mega Achdisty, 'Meningkatkan Kemampuan Berpikir Kritis Matematis Siswa Melalui Pendekatan Metacognitive Instruction', Mosharafa: Jurnal Pendidikan $\begin{array}{lll}\text { Matematika, } & 5.2 & \text { (2018), }\end{array}$ $<$ https://doi.org/10.31980/mosharafa.v5i2.267>

Nugrahaeni, Amallia, I Wayan Redhana, and I Made Arya Kartawan, 'Penerapan Model Pembelajaran Discovery Learning Untuk Meningkatkan Kemampuan Berpikir Kritis Dan Hasil Belajar Kimia', Jurnal Pendidikan Kimia Indonesia, 1.1 (2017), 23 <https://doi.org/10.23887/jpk.v1i1.12808>

Nur'aini, Nur'aini, 'Upaya Meningkatkan Kemampuan Metakognisi Melalui Strategi Pembelajaran PAI Berbasis DDCT Pada Mahasiswa Sekolah Tinggi Agama Islam Ibnu Sina Batam', Jurnal Pendidikan Agama Islam Al-Thariqah, 5.1 (2020), 10-18 <https://doi.org/10.25299/al-thariqah.2020.vol5(1).4682>

Nurfitriyanti, Maya, Novrita Mulya Rosa, and Fatwa Patimah Nursa'adah, 'Pengaruh Kemampuan Berpikir Kritis, Adversity Quotient Dan Locus of Control Terhadap Prestasi Belajar Matematika', JKPM (Jurnal Kajian Pendidikan Matematika), 5.2 (2020), 263 <https://doi.org/10.30998/jkpm.v5i2.5929>

Permana, Fendy Hardian, and Dwi Setyawan, 'Implementasi Mind Mapping Melalui Project Based Learning Untuk Meningkatkan Kemampuan Berpikir Kritis Dan Hasil Belajar', Jurnal Pijar Mipa, 14.1 (2019), 50 $<$ https://doi.org/10.29303/jpm.v14i1.1044>

Prasasti, Dianita Eka, Henny Dewi Koeswanti, and Sri Giarti, 'Peningkatan Keterampilan Berpikir Kritis Dan Hasil Belajar Matematika Melalui Model Discovery Learning Di Kelas Iv Sd', Jurnal Basicedu, 3.1 (2019), 174-79 $<$ https://doi.org/10.31004/basicedu.v3i1.98>

Prasetyo, A. A., \& Nabillah, T. Faktor Penyebab Rendahnya Hasil Belajar Siswa. Sesiomadika, 2019 
Purnaningsih, Wahyu, Stefanus Christian Relmasira, and Agustina Tyas Asri Hardini, 'Upaya Peningkatan Kemampuan Berpikir Kritis Dan Hasil Belajar Tematik Melalui Model Problem Based Learning (PBL) Kelas V SD', Naturalistic: Jurnal Kajian Penelitian Pendidikan Dan Pembelajaran, 3.2 (2019), 367-75 <https://doi.org/10.35568/naturalistic.v3i2.406>

Purwanto, Nfn, 'Tujuan Pendidikan Dan Hasil Belajar: Domain Dan Taksonomi', Jurnal Teknodik, 2019, 146 <https://doi.org/10.32550/teknodik.v0i0.541>

'Puspitasari, E., Sumarmi, \& Ach Amirudin. Integrasi Berpikir Kritis Dan Peduli Lingkungan Melalui Pembelajaran Geografi Dalam Membentuk Karakter Peserta Didik SMA. Jurnal Pendidikan: Teori, Penelitian, Dan Pengembangan, 1(2), (2016), 122-126.'.

'Putri, K., \& Dirgantoro, S., Mathline., Pendekatan Keterampilan Metakognitif Dalam Pembelajaran Matematika Metacognitive Skill Approach in Learning Mathematics. 3(1), (2018), 1-10.'

'Rachmady, R., Anggo, M., \& Busnawir, B., Analisis Metakognisi Dalam Pemecahan Masalah Matematika Siswa SMP. Jurnal Pembelajaran Berpikir Matematika (Journal of Mathematics Thinking Learning).', 2019

'Rahmawati., I. (n.d.). Analisis Keterampilan Berpikir Kritis Siswa SMP.Pdf.'

Ramdoniati, Nishfiya, Muntari Muntari, and Saprizal Hadisaputra, 'Pengembangan Bahan Ajar Kimia Berbasis Problem Based Learning Untuk Meningkatkan Keterampilan Metakognisi', Jurnal Penelitian Pendidikan IPA, 5.1 (2018) $<$ https://doi.org/10.29303/jppipa.v5i1.148>

'Redhana, I. W. (2019). Mengembangkan Keterampilan Abad Ke-21 Dalam Belajar Kimia. Jurnal Inovasi Pendidikan Kimia, 13(1), (2019), 2239 - 2253.'

Rhodes, Matthew G., 'Metacognition', Teaching of Psychology, 46.2 (2019), 168-75 <https://doi.org/10.1177/0098628319834381>

Rohman, Azizah Amatur, Suci Yuniarti, and Besse Intan Permatasari, 'Pengaruh Metakognisi Dan Kreativitas Terhadap Kemampuan Pemecahan Masalah Matematis Siswa Kelas X Ips Sma Negeri 4 Balikpapan Tahun Ajaran 2017/2018', De Fermat: Jurnal Pendidikan Matematika, 1.2 (2018), 25-30 <https://doi.org/10.36277/defermat.v1i2.23>

Safitri, Prahesti Tirta, Eprilita Yasintasari, Santi Adhitama Putri, and Uswatun Hasanah, 'Analisis Kemampuan Metakognisi Siswa Dalam Memecahkan Masalah Matematika Model PISA', Journal of Medives: Journal of Mathematics Education $\begin{array}{lllll}\text { IKIP Veteran } & \text { Semarang, } & 4.1 & \text { (2020), }\end{array}$ <https://doi.org/10.31331/medivesveteran.v4i1.941>

Saftari, Maya, and Nurul Fajriah, 'Penilaian Ranah Afektif Dalam Bentuk Penilaian Skala Sikap Untuk Menilai Hasil Belajar', Edutainment: Jurnal Ilmu Pendidikan Dan Kependidikan, 7.1 (2019), 71-81 <https://doi.org/10.35438/e.v7i1.164>

Sarjun., Konsep Ilmu Dalam Islam Dan Implikasinya Dalam Praktik Kependidikan. Al-Fikri. 2018

'Septiyani, D. Y., Haji, S., \& Widada, W., Meningkatkan Kemampuan Berpikir Kritis Calon Guru Matematika Melalui Aplikasi E-Learning Zoom Pada Mata Kuliah Microteaching Di Universitas Bengkulu. Jurnal Pendidikan Matematika Raflesia,'2020

'Setyaningrum, Defi. Utami., \& Mampouw, L., Helti, Proses Metakognisi Siswa SMP Dalam Pemecahan Masalah Perbandingan Senilai Dan Berbalik Nilai. Mosharafa: Jurnal Pendidikan Matematika, 2020

Sharfina, Dini, Hubungan Berpikir Kritis Perawat Dalam Proses Pengambilan Keputusan Keperawatan (Open Science Framework, September 28 ${ }^{\text {th }}, 2019$ ) <https://doi.org/10.31219/osf.io/zjh82>

Shea, Nicholas, 'Concept-metacognition', Mind \& Language, 35.5 (2020), 565-82 <https://doi.org/10.1111/mila.12235> 
Sholihah, Dyahsih Alin, Widha Nur Shanti, and Ahmad Anis Abdullah, 'Model Experiential Learning Untuk Meningkatkan Kemampuan Berpikir Kritis Mahasiswa Pendidikan Matematika', UNION: Jurnal Ilmiah Pendidikan Matematika, 7.3 (2019), 383 <https://doi.org/10.30738/union.v7i3.5844>

Siregar, Suriani, 'Analisis Keterampilan Metakognitif Dan Sikap Ilmiah Siswa Melalui Metode Pembelajaran Inkuiri', Biotik: Jurnal Ilmiah Biologi Teknologi Dan Kependidikan, 7.2 (2019), 141

<https://doi.org/10.22373/biotik.v7i2.5665>

Story, David A., and Alan R. Tait, 'Survey Research', Anesthesiology, 130.2 (2019), 192202 <https://doi.org/10.1097/ALN.0000000000002436>

Sugeng, B., Fundamental Metodologi Penelitian Kuantitatif. In Komunikasi Penelitian Kuantitatif Program Studi Jurnalistik \& Humas. 2020

Sukaisih, R., Muhali, M., \& Asy'ari, M., Meningkatkan Keterampilan Metakognisi Dan Berpikir Kritis Siswa Melalui Pembelajaran Model Pemecahan Masalah Dengan Strategi Konflik-Kognitif. Empiricism Journal, 2020

Sukarno, and M. El Widdah, 'The Effect of Students' Metacognition and Digital Literacy in Virtual Lectures during the Covid-19 Pandemic on Achievement in the "Methods and Strategies on Physics Learning" Course. Jurnal Pendidikan IPA Indonesia', $2020<$ https://doi.org/10.15294/jpii.v9i4.25332>

Sulistiani, E., \& Masrukan., Pentingnya Berpikir Kritis Dalam Pembelajaran Matematika Untuk Menghadapi Tantangan MEA. Seminar Nasional Matematika X Universitas Semarang, 2016.

Suparni, Suparni, 'Upaya Meningkatkan Kemampuan Berpikir Kritis Mahasiswa Menggunakan Bahan Ajar Berbasis Integrasi Interkoneksi', Jurnal Derivat: Jurnal Matematika Dan Pendidikan Matematika, $3.2 \quad$ (2020), 40-58 <https://doi.org/10.31316/j.derivat.v3i2.716>

'Tridellya, F., Anisa, R., \& Damayanti, D. S., Korelasi Motivasi Dan Kesiapan Belajar Mandiri Terhadap Kelulusan Computer Based Test Uji Kompetensi Mahasiswa Program Profesi Dokter Universitas Islam Malang. Jurnal Bio Komplementer Medicine,' 2019

Ulichusna, Ayu Arsya, Tri Hariyati Nur Indah Sari, and Ganjar Susilo, 'Pengaruh Metakognisi Dan Keaktifan Belajar Siswa Terhadap Hasil Belajar Matematika', Kompetensi, 12.1 (2019), 44-52 <https://doi.org/10.36277/kompetensi.v12i1.21>

'Widodo, F. S. L. W., Sofya, E., \& Efkar, T., Efektivitas Inkuiri Terbimbing Untuk Meningkatkan Keterampilan Metakognisi Siswa Materi Larutan Elektrolit Dan Non Elektrolit. Jurnal Pendidikan Dan Pembelajaran Kimia,' 2019

Zubaidah, S., Malang, U. N., \& Aloysius, D. C. (2018). Asesmen Berpikir Kritis Terintegrasi Tes Essay Asesmen Berpikir Kritis Terintegrasi Tes Essay. April 2015. 
